\title{
LOCAL AXIAL MIGRATION AND SPREADING RATE VARIATIONS, EAST PACIFIC RISE, $31^{\circ} \mathrm{S}^{1}$
}

\author{
DAVID K. REA \\ Department of Atmospheric and Oceanic Science, The University of Michigan, Ann Arbor, Mich. 48109 (USA)
}

Received October 7, 1976

Revised version received November 29, 1976

\begin{abstract}
Mapping and analysis of marine magnetic anomalies generated during the past $3.78 \mathrm{~m} . \mathrm{y}$. at the East Pacific Rise crest near $31^{\circ} \mathrm{S}$ reveals a history of ongoing small-scale migration of the spreading center. The axis first became curved and then broke when the curvature became too severe, forming a $10-\mathrm{km}$ offset. The offset healed rapidly and the topographic axis of the rise is now continuous and essentially linear. Sea-floor spreading has occurred asymmetrically in this area with east and west flank rates of 86 and $77 \mathrm{~mm} / \mathrm{yr}$, respectively, since $2.41 \mathrm{~m} . \mathrm{y}$. ago. Total spreading rates show an overall decline from 176 to $145 \mathrm{~mm} / \mathrm{yr}$ prior to the Jaramillo event, $0.9 \mathrm{~m} . \mathrm{y}$. ago. For the last 0.7 m.y. the total spreading rate has been $162 \mathrm{~mm} / \mathrm{yr}$.
\end{abstract}

\section{Introduction}

The East Pacific Rise (EPR) along the western edge of the Nazca lithospheric plate forms the most rapidly spreading portion of the oceanic ridge system. The spreading regime along the northern portion of this plate boundary is relatively simple $[1-3]$ but, between about $22^{\circ} \mathrm{S}$ and the triple junction at $34^{\circ} \mathrm{S}$, the EPR is complicated by the probable existence of two small "mini-plates", one between about $22^{\circ}$ and $26^{\circ} \mathrm{S}$ and another at approximately $32^{\circ}$ to $34^{\circ} \mathrm{S}$ [4-6]. Reconnaissance data available in 1973 suggested that the region along the EPR crest near $31^{\circ} \mathrm{S}$ was the southernmost location of relatively uncomplicated sea-floor spreading along the Nazca-Pacific plate boundary, and a survey for that region was planned to complete the suite of four rise-crest surveys obtained under the auspices of the Nazca Plate Project (Fig. 1, inset). In comparison with the other survey areas, however, the data suite near $31^{\circ} \mathrm{S}$ is relatively restricted, consisting of only four tracklines across the axial region (Fig. 1). Therefore the results and interpretations presented here must be taken as

1 Department of Atmospheric and Oceanic Science, Contribution No. 235. probabilities and not near certainties as can often be assumed for areas with more detailed coverage.

Information presented here was obtained by the $\mathrm{R} / \mathrm{V}$ "Yaquina" of Oregon State University (cruise Y-73, leg 4) and by the NOAA ship "Oceanographer" in 1970 and 1973. Satellite navigation and routine methods of data processing were used.

\section{The EPR crest at $30^{\circ} \mathrm{S}$}

The bathymetric features of the EPR axial region at $31^{\circ} \mathrm{S}$ are generally similar to those observed elsewhere along the Nazca-Pacific plate boundary $[1,2]$. The spreading axis is marked by a low ridge $450-500$ $\mathrm{m}$ high, about $20 \mathrm{~km}$ wide at the base, and trending $012^{\circ}$ along about $111.9^{\circ} \mathrm{W}$ (Figs. 2 and 3). Bathy. metric profiles of the survey area (Fig. 3) reveal that the flanks of the axial ridge are fairly smooth and that abyssal hills $100-200 \mathrm{~m}$ high occur on either side of the axis. In other EPR crest survey areas [1,2] these hills are strongly lineated parallel to the axis, but such a lineation is not as apparent in this area (Fig. 2). Because this usual lineation may be absent at $31^{\circ} \mathrm{S}$, bathymetric contours, except for those along the axial ridge, have not been extended between the 


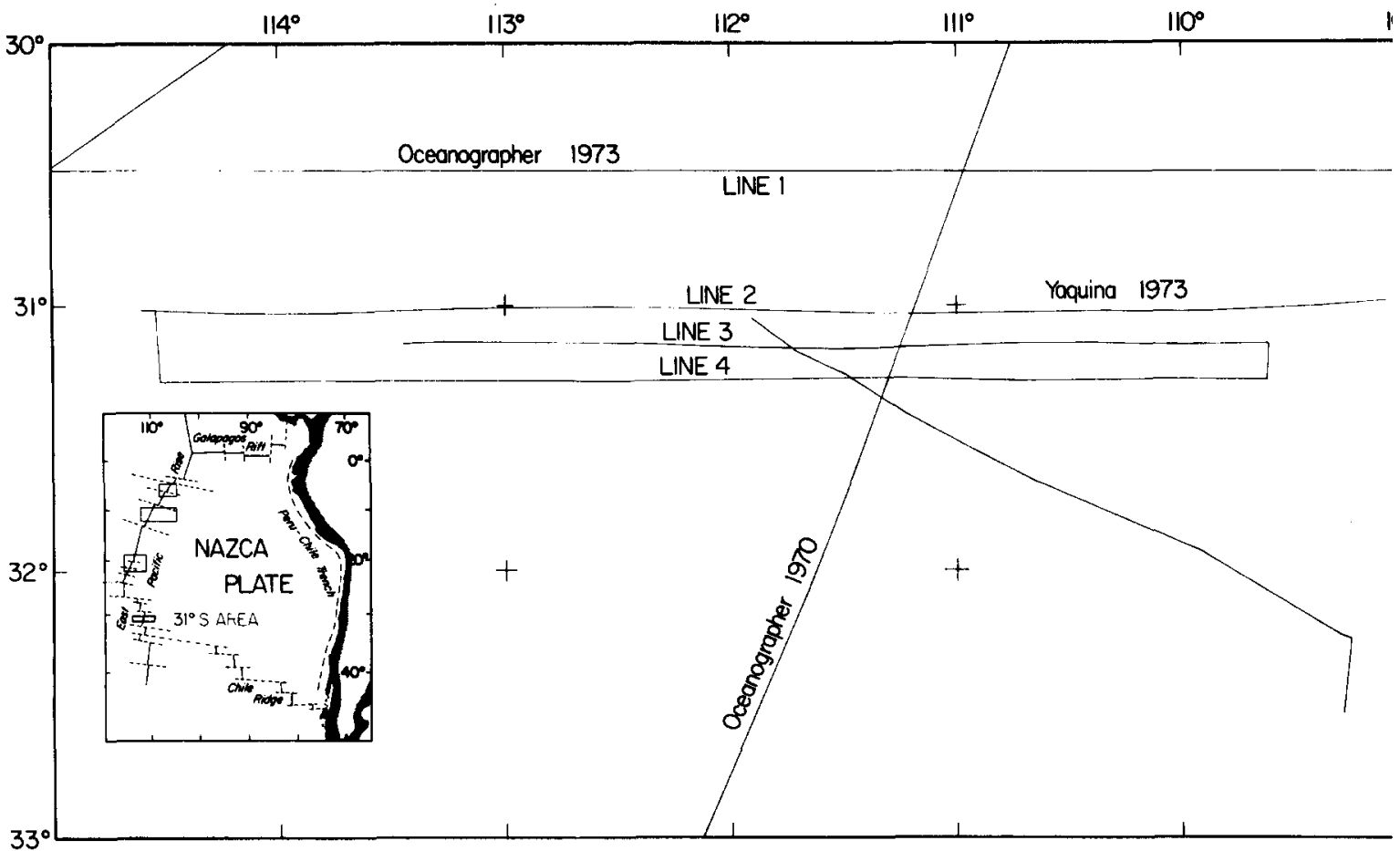

Fig. 1. Location of the EPR survey area (inset) and tracklines in the $31^{\circ} \mathrm{S}$ region.

more widely spaced tracklines. Several isolated peaks occur in the survey area, the largest of which is a 2050 $\mathrm{m}$ high seamount occurring at about $31^{\circ} \mathrm{S}, 113^{\circ} \mathrm{W}$; other smaller peaks occur throughout the area.
South of the rise crest survey a large, north-facing scarp, 1200-1300 m high, apparently trends about $098^{\circ}$ between the two tracklines that cross it (Figs. 2 and 4 ). This feature, located at about $31.8^{\circ} \mathrm{S}$ is the

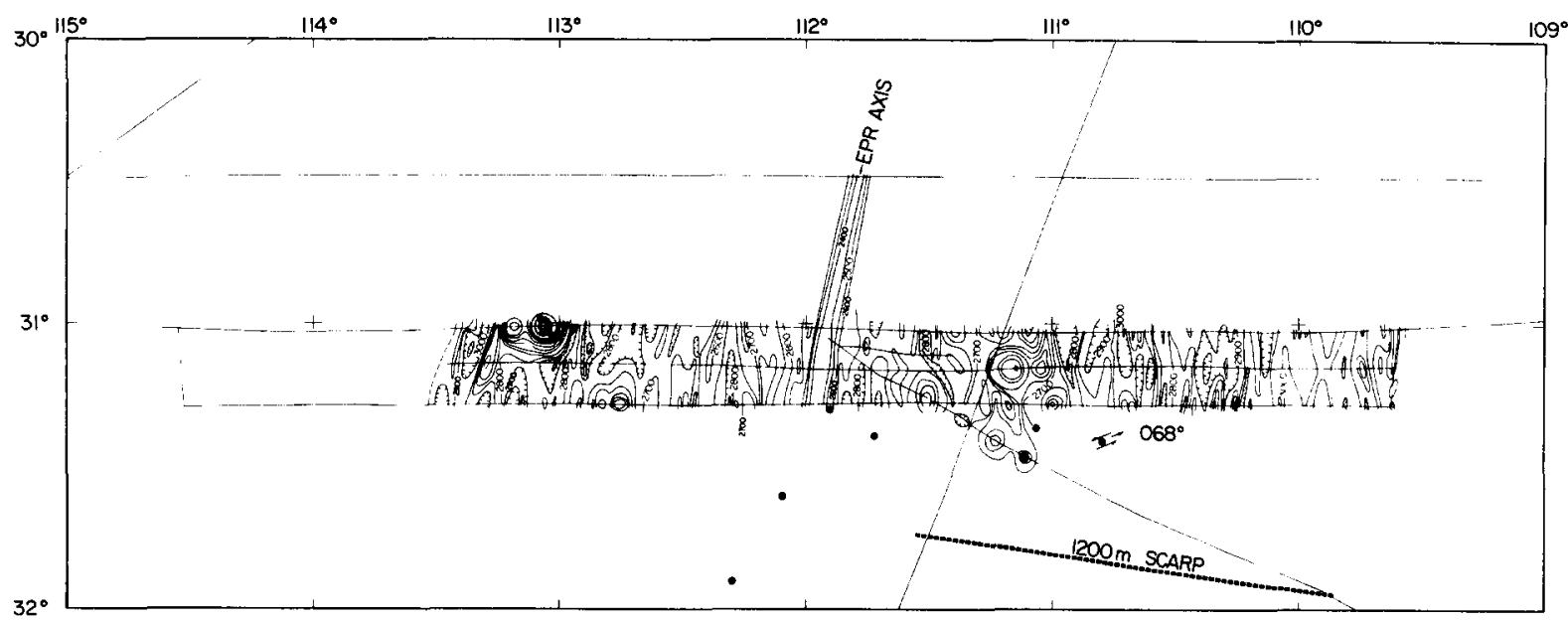

Fig. 2. Bathymetric map of the $31^{\circ} \mathrm{S}$ survey area. Depths in corrected meters; contour interval is $100 \mathrm{~m}$. Dots denote earthquake epicenters. 


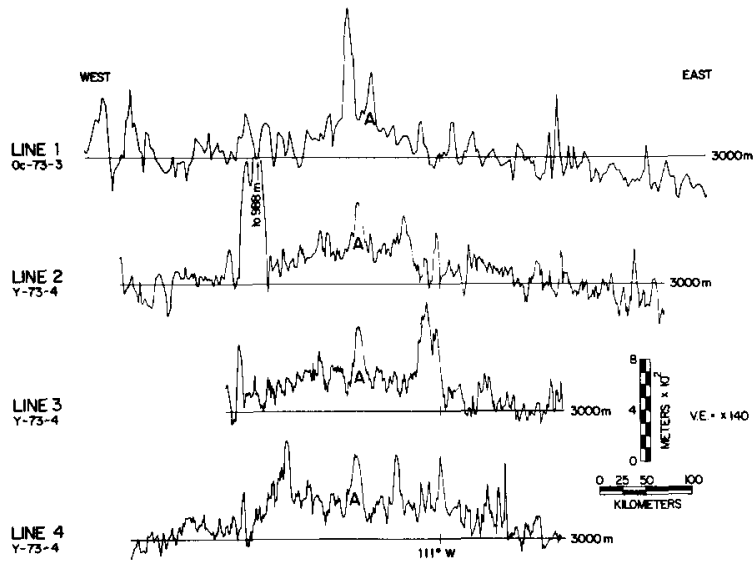

Fig. 3. Bathymetric profiles from the $31^{\circ} \mathrm{S}$ survey area. Horizontal lines denote $3000 \mathrm{~m}$ depth. Topographic axis of EPR denoted by $A$. Vertical dashes indicate where profiles cross $111^{\circ} \mathrm{W}$. The apparent difference in short wavelength topography results from different digitization procedures utilized by NOAA (line 1) and Oregon State University (lines 2--4). Profile locations given in Fig. 1. West is to the left.

approximate northern limit of a region of extremely rough, broken topography. (My bathymetric correlation is between the northernmost large-scale feature on each line, other correlations may be equally probable; see Fig. 4.) A dredge haul recovered from the south side of this feature further to the southeast

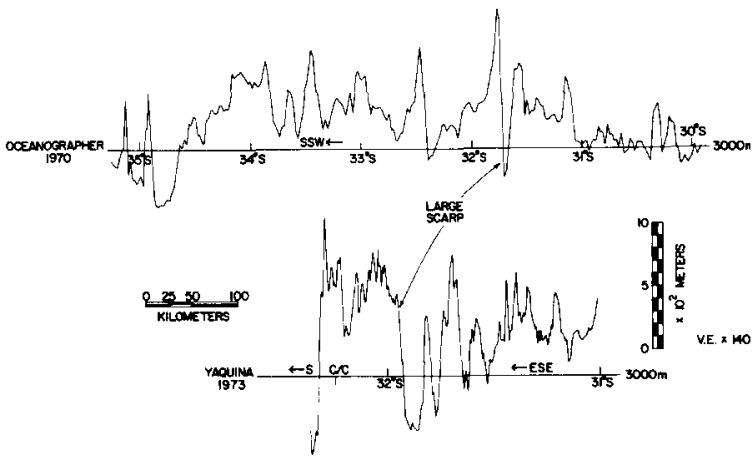

Fig. 4. Bathymetric profiles across the region of rough topog. raphy south of $31^{\circ} \mathrm{S}$ survey area. Profile locations given in Fig. 1.

$\left(32.5^{\circ} \mathrm{S}, 109.3^{\circ} \mathrm{W}\right)$ recovered basalts, sheared greenschists, and altered, coarse-grained dolerite (J.B. Corliss, written communication, 1974).

Linear magnetic anomalies within the region surveyed are 400-600 $\gamma$ in amplitude and are easily identified (Figs. 5 and 6). Magnetic anomalies associated with the Matuyama/Gauss reversal at $2.41 \mathrm{~m} . \mathrm{y}$ ago (anomaly $2^{\prime}$ ), the Olduvai event centered at 1.73 m.y. (anomaly 2 ) and the Brunhes/Matuyama reversal at $0.7 \mathrm{~m} . y$. ago are evident on all four profiles. The Jaramillo event centered at 0.92 m.y. ago (time scale from Klitgord [7]) is ambiguous along the western portion of line 3 (Fig. 6). The magnetic

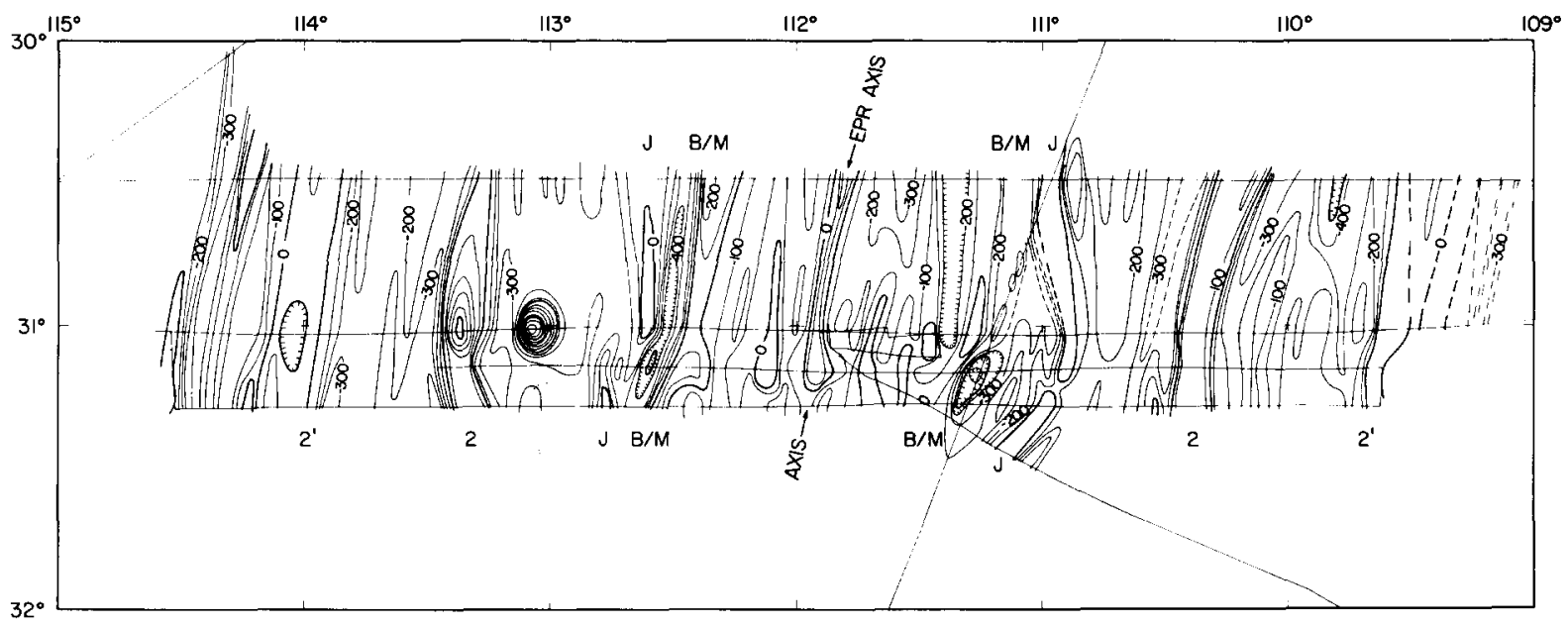

Fig. 5. Magnetic anomaly map of the $31^{\circ} \mathrm{S}$ survey area. Contour interval is $100 \gamma$. Linear magnetic anomalies $2^{\prime}$ and 2 and those corresponding to the Jaramillo event $(\mathrm{J})$ and the Brunhes/Matuyama reversal $(\mathrm{B} / \mathrm{M})$ are indicated. 


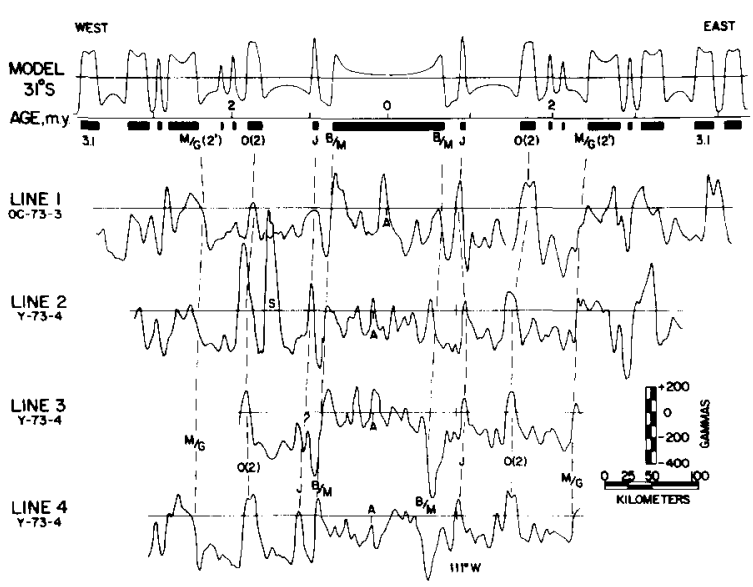

Fig. 6. Observed and calculated magnetic anomaly profiles from the $31^{\circ} \mathrm{S}$ survey area. Anomaly designations as in Fig. 5 and in text. Horizontal line denotes $0 \gamma . A$ denotes location of EPR topographic axis; $S$ on line 2 indicates anomaly produced by the large seamount. Vertical dashes across the $0-\gamma$ line show where profiles cross $111^{\circ} \mathrm{W}$. Profile locations given in Fig. 1. West is to the left.

anomaly map (Fig. 5) shows that the contoured Jaramillo anomalies on either flank of the rise are not parallel to each other between lines 1 and 2 . This is in conflict with the basic concept of linear magnetic anomaly generation at a single axis and suggests that additional complications in the spreading process occurred about the time of the Jaranillo event. One other anomaly can be correlated across the entire rise crest survey area, the 200-300 $\gamma$ amplitude anomaly that occurs in conjunction with the axial ridge. Similar anomalies found elsewhere are thought to be caused by highly magnetized, unweathered basalt occurring at the spreading center $[8-10]$.
Mapping of the anomalies (Fig. 5) shows that the Matuyama/Gauss anomaly $\left(2^{\prime}\right)$ is relatively straight, anomaly 2 is curved and the Jaramillo anomaly apparently is offset about $10 \mathrm{~km}$ right-laterally between lines 3 and 4 . The Brunhes/Matuyama anomaly is curved but continuous in the same region. These changes in the anomaly configuration record 0.7$1.7 \mathrm{~m} . \mathrm{y}$. old complications of the otherwise straightforward spreading process at $31^{\circ} \mathrm{S}$.

Crustal accretion rates were determined by measuring the distance between anomalies in a direction orthogonal to the axial ridge and dividing by the appropriate time interval [7]. Results of such calculations (Table 1) show a total accretion rate of 163 $\mathrm{mm} / \mathrm{yr}$ since the time of the Matuyama/Gauss reversal. Spreading half-rates, however, have not been equal during the past $2.41 \mathrm{~m} . y$., as crustal accretion has averaged about $77 \mathrm{~mm} / \mathrm{yr}$ to the west and $86 \mathrm{~mm} / \mathrm{yr}$ to the east. During the last 0.7 m.y. the total spreading rate has been about the same as the overall average, $162 \mathrm{~mm} / \mathrm{yr}$. Complications in the spreading process are suggested by the variation in half- and -wholerates occurring between the times of the Olduvai event and the Brunhes/Matuyama reversal as well as by the offset of the Jaramillo anomaly.

\section{Local migration of the axis}

Information presented on the magnetic anomaly map (Fig. 5) contains evidence for the local migration of the spreading center. Past axial configurations can be recreated from the anomaly pattern (Fig. 7) demonstrating axial migration. Between the times of anom alies $2^{\prime}$ and 2, 2.41-1.73 m.y. ago, the axis changed

TABLE 1

Sea-floor spreading rates in $\mathrm{mm} / \mathrm{yr}$ or $\mathrm{km} / 10^{6} \mathrm{yr}$ for the East Pacific Rise at $31^{\circ} \mathrm{S}$

\begin{tabular}{lllcl}
\hline Anomaly interval & Age (m.y. ago) & West flank & East flank & Total \\
\hline $3.1-2^{\prime} *$ & $3.78-2.41$ & 81.3 & 94.5 & 175.8 \\
$2^{\prime}-2$ & $2.41-1.73$ & 74.0 & 92.7 & 166.7 \\
$2-\mathrm{J}$ & $1.73-0.92$ & 77.2 & 67.9 & 145.1 \\
J-B/M & $0.92-0.70$ & 70.9 & 151.8 & 222.7 \\
B/M-axis & $0.70-0.0$ & 80.8 & 80.8 & 161.6 \\
Overall, 2'-axis & & 76.8 & 86.3 & 163.1 \\
\hline
\end{tabular}

* Only one measurement. 


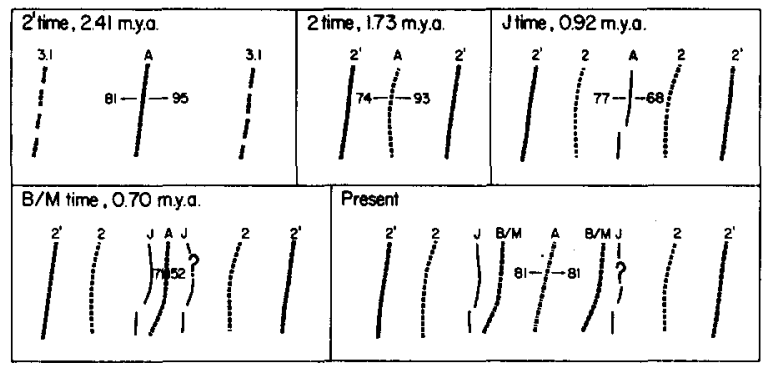

Fig. 7. Reconstruction of past axis and anomaly configurations for the EPR at $31^{\circ} \mathrm{S}$ illustrating the changing axis configurations. Numbers are spreading rates in $\mathrm{mm} / \mathrm{yr}$ for the appropriate interval.

from linear to concave to the east. Some time prior to the formation of the Jaramillo anomaly a $10-\mathrm{km}$ offset of the axis occurred where it had been curved. This offset was such that the southern portion of the axis was set to the west, the direction opposite to that expected from the curvature in anomaly 2 . During the brief period between Jaramillo time and the Brunhes/Matuyama reversal the small axial offset was healed but the axis remained curved in the same manner as the offset. At present, the topographic axis of the EPR is nearly linear.

Thus, the available data suggest a rise that is constantly changing its configuration. Such local axial migrations were suggested by Blakely [11] to explain apparent fluctuations in northeast Pacific spreading rates. When axial curvature becomes too severe, it is relieved by the creation of a small offset. At $31^{\circ} \mathrm{S}$, at least, the small axial offset apparently acted to return the spreading axis to a more central position rather than to shift the axis in the direction of curvature. This, in turn, suggests that the position of the spreading axis is sensitive to the location of the underlying magma and heat sources and may migrate or jump in order to remain at the preferred location. The thin lithosphere found in the axial regions of fast-spreading rises may not have the mechanical strength required to have one unvarying central break, hence the observed changing configurations.

\section{Variations in spreading rate}

Calculations of sea-floor spreading rates for each rise flank and anomaly-bound time interval (Table 1) are sensitive to one's choice of time scale but, regardless of the time scale chosen, certain facts remain. Asymmetrical spreading, faster to the east, is the normal mode of crustal accretion along this portion of the East Pacific Rise. Exceptions to this generalization evidently occurred between about 1.7 and $1.0 \mathrm{~m} . \mathrm{y}$. ago (the time of the $10-\mathrm{km}$ axial offset) when spreading was faster to the west, and between $0.7 \mathrm{~m} . y$. ago and the present when the accretion process was symmetrical (Table 1). The extreme asymmetry occurring during the Jaramillo to Brunhes/Matuyama interval is at least partially an artifact of (1) changing axial configuration, and (2) the fact that these changes occurred over a very short time period, 0.22 m.y.; a similar spatial change over a longer time period would have much less effect on the apparent spreading rates. Overall, during the entire Olduvai to Brunhes/Matuyama interval the east and west flank spreading rates are about 86 and $76 \mathrm{~mm} / \mathrm{yr}$, respectively.

As well as the variations in accretion rate that occur on each flank, the total rates also vary (Table 1). Beginning at least $3.78 \mathrm{~m} . y$. ago, the age of anomaly 3.1 [12], there has been a gradual reduction in spreading rate ending during the Olduvai to Jaramillo time interval, centered at $1.3 \mathrm{~m} . y$. ago, with a low value of about $145 \mathrm{~mm} / \mathrm{yr}$. This relatively low rate was followed by a brief spurt of very rapid spreading during the short Jaramillo to Brunhes/Matuyama time interval. The cause of this brief and rapid interlude of spreading, which appears entirely confined to the east flank of the rise, is not known, although also during this same time interval the small axis offset was healed by some migration of the axis. However, there is no a priori reason why the process of axial migration should effect the total spreading rate and the geographic coincidence of these two processes need not require a causal relationship. Since the Brunhes/Mat uyama reversal 0.7 m.y. ago, accretion has occurred at a total rate of about $162 \mathrm{~mm} / \mathrm{yr}$.

\section{Regional considerations}

The small survey at $31^{\circ} \mathrm{S}$ is situated only a few tens of kilometers north of the suggested mini-plate at about $32^{\circ}$ to $34^{\circ} \mathrm{S}$ [4-6]. Only subtle hints of this nearby tectonic complexity can be found in the survey area; the linearity of the abyssal hills is less 
regular than elsewhere on the EPR, and there appears to be more extrusive features in the axial region here than in the other three survey areas [1-3]. These two characteristics may indicate less regular but more extensive faulting in this axial region at $31^{\circ} \mathrm{S}$.

Forty to fifty kilometers to the south a region of rugged bathymetry begins (Fig. 4). The northernmost large scarp of this topographically disturbed region appears to trend $098^{\circ}$ (Figs. 2 and 4), a direction slightly closer to the $105^{\circ}$ trend of Pacific-Nazca transform faulting [6] than the roughly $085^{\circ}$ direction of Antarctic-Nazca transform motion at the Chile Rise $[5,6]$. Six earthquake epicenters occur in the region between $31^{\circ}$ and $32^{\circ} \mathrm{S}$ (Fig. 2). It is possible that the four northern epicenters lying along about $31.4^{\circ} \mathrm{S}$ could denote a transform fault but there is no axial offset or other strong bathymetric or magnetic evidence for such a feature within the survey area. Forsyth [5] has determined the focal mechanism of the easternmost earthquake $\left(31.4^{\circ} \mathrm{S}, 110.8^{\circ} \mathrm{W}\right)$ which showed left-lateral strike-slip faulting trending $068^{\circ}$. Both the direction of motion and sense of first motion of this faulting are inconsistent with transform motion between the axis at $31^{\circ} \mathrm{S}, 112^{\circ} \mathrm{W}$, and another section of the spreading center to the southeast. Unless the region just to the south is extremely complicated, this event also probably does not represent motion along the northern boundary of a mini-plate but is just another manifestation of the tectonic complexity of this region north of the Pacific-Nazca-Antarctic triple junction $[4,5,13]$.

Between $34^{\circ}$ and $35^{\circ} \mathrm{S}$ the Oceanographer 1970 line crosses the southern limit of this topographically disturbed zone (Fig. 4) where the sea floor descends to the south about $1000 \mathrm{~m}$ in two steps. Along this trackline then, the region of rough topography extends from $31.7^{\circ} \mathrm{S}, 111.5^{\circ} \mathrm{W}$, south to $34.7^{\circ} \mathrm{S}$, $112.9^{\circ} \mathrm{W}$.

\section{Summary}

Mapping the bathymetry and magnetic anomalies occurring near the EPR axis at $31^{\circ} \mathrm{S}$ reveals that the present topographic axis of the rise is straight but that the sea-floor spreading anomalies, which record prior axial positions, are often curved or offset (Figs. 2 and 5). These data are interpreted as recording a sequence of local axial migrations that have continued for at least the past 2.4 m.y. During this time the EPR axis has apparently changed its configuration from linear to curved to offset and back to linear (Fig. 7). It is not surprising to find evidence of ongoing local axial migrations on fast-spreading rises because such regions contain relatively wide areas of young, thin lithosphere that cannot physically confine the spreading center as readily as the much more rapidly thickening lithosphere adjacent to slow-spread. ing ridges. For example, at the respective spreading rates [14] a region $230 \mathrm{~km}$ wide at $31^{\circ} \mathrm{S}$ on the EPR has the same age as the $31 \mathrm{~km}$ wide axial valley at $36.5^{\circ} \mathrm{N}$ on the Mid-Atlantic Ridge. If lithospheric thickness is proportional to $t$ (age) ${ }^{1 / 2}$ [15], then at any given distance from the axis, north Atlantic lithosphere will be about 2.7 times thicker than that generated by the EPR along the west edge of the Nazca plate.

Local or regional asymmetries in spreading rates do not imply that the total rate of crustal accretion must be changing, yet these rates also vary in the $31^{\circ} \mathrm{S}$ survey area. Spreading rates slowed from 3.8 to about $1.3 \mathrm{~m} . \mathrm{y}$. ago and then underwent a brief, rapid, spurt during the Jaramillo to Brunhes time interval before slowing to a rate of about $162 \mathrm{~mm} / \mathrm{yr}$ over the last 0.7 m.y.

\section{Acknowledgements}

Most of the data processing for this report was completed while the author was at the School of Oceanography, Oregon State University. This manuscript has benefitted from reviews by R.J. Blakely and K.F. Scheidegger.

The work was supported by the National Science Foundation via the International Decade of Ocean Exploration Nazca Plate Project grant GX-28675.

\section{References}

1 D.K. Rea, Changes in the axial configuration of the East Pacific Rise near $6^{\circ} \mathrm{S}$ during the past 2 m.y., J. Geophys. Res. 81 (1976) 1495.

2 D.K. Rea, Analysis of a fast-spreading rise crest: the East Pacific Rise, $9^{\circ}$ to $12^{\circ}$ South, Mar. Geophys. Res. (1976) in press. 
3 D.K. Rea, Variable asymmetric sea-floor spreading, East Pacific Rise, $20^{\circ} \mathrm{S}$, Trans. Am. Geophys. Union 56 (1975) 443.

4 E.M. Herron, Two small crustal plates in the South Pacific near Easter Island, Nature Phys. Sci. 240 (1972) 35.

5 D.W. Forsyth, Mechanisms of earthquakes and plate motions in the East Pacific, Earth Planet. Sci. Lett. 17 (1972) 189.

6 R.N. Anderson, D.W. Forsyth, P. Molnar and J. Mammerickx, Fault plane solutions of earthquakes on the Nazca plate boundaries and the Easter plate, Earth Planet. Sci. Lett. 24 (1974) 188.

7 K.D. Klitgord, Near-bottom geophysical surveys and their implications on the crustal generation process, seafloor spreading history of the Pacific, and the geomagnetic time scale: 0 to 6 m.y. B.P., Ph.D. Thesis, Univ. of California, San Diego, Calif. (1974) 177 pp.

8 K.D. Klitgord and J.D. Mudie, The Galapagos spreading center: a near-bottom geophysical survey, Geophys. J.
R. Astron. Soc. 38 (1974) 563.

9 D.K. Rea and R.J. Blakely, Short-wavelength magnetic anomalies in a region of rapid sea-floor spreading, Nature 255 (1975) 126.

10 K.D. Klitgord, Sea-floor spreading: the central anomaly magnetization high, Earth Planet. Sci. Lett. 29 (1976) 201.

11 R.J. Blakely, Evidence of local migration of a spreading center, Geology 3 (1975) 35.

12 M. Talwani, C.C. Windisch and M.G. Langseth, Jr., Reykjanes Ridge crest: a detailed geophysical study, J. Geophys. Res. 76 (1971) 473.

13 C.W. Stover, Seismicity and tectonics of the East Pacific Ocean, J. Geophys. Res. 78 (1973) 5209.

14 H.D. Needham and J. Francheteau, Some characteristics of rift valley in the Atlantic Ocean near $36^{\circ} 48^{\prime}$ north, Earth Planet. Sci. Lett. 22 (1974) 29.

15 R.L. Parker and D.W. Oldenburg, Thermal model of ocean ridges, Nature Phys. Sci. 242 (1973) 137. 